\title{
Operating And Earnings Performance Of Quality Certified Listed Firms
}

Eurico J. Ferreira, Indiana State University, USA

Amit Sinha, Indiana State University, USA

Dale Varble, Indiana State University, USA

\begin{abstract}
With a large number of US firms, obtaining the ISO 9000 quality certification, this article attempts to investigate the impact of the certification on operating and financial performance. Our results indicate the benefits of the certification may be limited and may depend on the time period in consideration, and the sample of firms used for comparing firm performance. Also investors usually do not perceive the ISO certified firms to have a higher quality of earnings and not willing to pay more for earnings from such firms.
\end{abstract}

Keywords: ISO9000 quality certification, abnormal operating performance, and control firms.

\section{INTRODUCTION}

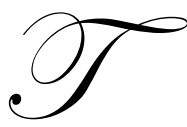

he importance of the ISO 9000 certificate as a measure of quality management has grown exponentially over the last decade. The number of certificates awarded globally has increased from less than fifty thousand certificates by the end of 1993, to almost five hundred thousand certificates by the end of 2001 were awarded in over 161 countries. Within the United States over a thousand firms obtained certification in the same period. As the primary objective of the ISO certification is to 'promote the development of standardization and related activities in the world with a view to facilitating the international exchange of goods and services, and to developing cooperation in the spheres of intellectual, scientific, technological and economic activity,' the question remains whether the firm or its shareholders are able to realize any benefit by going through the certification process. Whereas Ferreira, Sinha and Varble (2006) investigate this issue from the perspective of shareholders, this paper investigates from the perspective of the firm.

There is a lot of controversy surrounding the benefits of the ISO certification. While Quaze, Hong and Meng, (2002) think that an ISO certificate improves the product and service quality, efficiency and productivity, customer confidence, and competitive advantage, Dalgleish (2002) points out that the "pass/fall" mentality of the ISO process basically hinders the very thing it is supposed to encourage. Dalgleish (2002) also thinks that the ISO process requires inordinate and unnecessary paperwork.

Chittenden, Poutziouris, and Mukktar (1998) point out that in the opinion of ISO users, the disadvantages of certification process does not match up with the benefits. MacAdam and McKeown (1999), however, think that the ISO certificate may result in better control of business, increased sales, reduced costs, increased productivity and higher customer satisfaction. Anderson, Daly, and Johnson (1999) also show that North American manufacturing firms have successfully used the ISO certificate as a credible signal of quality assurance, and Sun (1999) concludes that the certificate results in both fewer defective products and fewer customer complaints.

Although the ISO 9000 quality certificate has been around for more than a decade, only a few articles have empirically investigated the benefits, if any, to the firm from the ISO certification. Most of the empirical studies have investigated non-US firms, and the few that have investigated US firms have considered only a few industries. For example, Sharma (2005) studied firms listed in Singapore, Heras, Dick, and Casadesus (2002) studied Spanish firms, and Beira and Cabral (2002) investigated Portuguese firms. Corbett, Montes, Kirsch and Alvarez-Gil (2002), 
Corbett, Montes-Sancho, and Kirsch (2005), and Simmons and White (1999) investigate US firms. While Simmons and White (1999) use a sample with just 63 firms, Corbett, Montes, Kirsch and Alvarez-Gil (2002), consider 373 firms from just three industries, and Corbett, Montes-Sancho, and Kirsch (2005) use 554 manufacturing firms. Thus, this article differs from Sharma (2005), Heras, Dick, and Casadesus (2002), and Beira and Cabral (2002) as we consider U.S. firms. It also differs from Simmons and White (1999), Corbett, Montes, Kirsch and Alvarez-Gil (2002), and Corbett, Montes-Sancho, and Kirsch (2005) in terms of the number of industries considered. While Simmons and While (1999) consider only one industry, Corbett, Montes, Kirsch and Alvarez-Gil (2002) consider three, and Corbett, Montes-Sancho, and Kirsch (2005) consider only manufacturing firms. Our study sample includes 42 industries 448 firms.

This article also differs from Corbett, Montes, Kirsch and Alvarez-Gil (2002), and Corbett, MontesSancho, and Kirsch (2005), in terms of the sample period considered. While the sample period in Corbett, Montes, Kirsch and Alvarez-Gil (2002) and Corbett, Montes-Sancho, and Kirsch (2005) are between 1990 and 1997, the sample in our study is between 1991 and 2002. Moreover, this work differs from Corbett, Montes, Kirsch and Alvarez-Gil (2002), and Corbett, Montes-Sancho, and Kirsch (2005) in terms of the variable considered, and the selection of control firms. The variables considered in Corbett, Montes, Kirsch and Alvarez-Gil (2002), and Corbett, Montes-Sancho, and Kirsch (2005) are return on assets, return on sales, Tobin's Q, and cost to sales ratio, while in our paper we consider sales, cost of goods sold, gross profit, net income, operating earnings per share, basic earnings per share including extra-ordinary items, return on equity, return on assets, and return on investments. In addition, we also investigate investors' perception about the quality of operating and financial earnings. To obtain proper comparisons, we also scale our sales, cost of goods sold, gross profit and net income with total assets. Moreover, we select the control group in the year of the certification, while Corbett, Montes, Kirsch and Alvarez-Gil (2002), and Corbett, Montes-Sancho, and Kirsch (2005) select their control group two years before certification.

Our findings indicate that there may be some operating and financial performance benefits for firms to pursue the certification. However, these benefits may depend on economic cycle, variables considered, and the control group of firms used for comparison purposes. Our findings do not overwhelmingly support performance benefits to firms, nor does it overwhelmingly reject it. Investors' perception about differences in quality of earnings may also be limited. The rest of the paper is divided into data and methodology (Section 2) results (Section 3) and conclusion (Section 4).

\section{DATA AND METHODOLOGY}

The data used in this study is the same as that used in Ferreira, Sinha and Varble (2006) which was shared with us by Quality Digest. ${ }^{1}$ The data which included company name, location, country, certification date, and type of certification, was merged with CRSP and COMPUSTAT ${ }^{2}$ data using CUSIP identifiers. The market price was obtained from CRSP. The data variables obtained from COMPUSTAT are common equity, total assets, number or outstanding shares, 4-digit SIC codes, sales, cost of goods sold, gross profit, net income, return on assets, return on equity, return on investments, earnings per share from operations ${ }^{3}$ (EPSO), and basic earnings per share that

\footnotetext{
${ }^{1}$ Mr. Dirk Dusharme, Technology Editor, has been our point of contact. Quality Digest address is 40 Declaration Drive, ste.100, Chico, CA.

${ }^{2}$ The COMPUSTAT data was obtained from Kent State University, while one of the authors (Dr. Amit Sinha) was still a graduate student there.

${ }^{3}$ The earnings per share from operations are adjusted to remove the effect of all special items from the calculation. It reflects a figure that excludes the effect of all nonrecurring events. COMPSTAT data item number is A233. This excludes cumulative effect of accounting change, discontinued operations, extraordinary items, special items and one-time income tax expenses/benefits.
} 
includes extra items ${ }^{4}$ (EPSI).The first two digits of the four-digit SIC codes were used to obtain the two-digit SIC $\operatorname{codes}^{5}$. Data extracted from CRSP and COMPUSTAT are at annual frequency.

After merging the ISO, CRSP and COMPUSTAT data, firms with zero or negative common equity, cost of goods sold, total assets and sales were discarded. Also firms were discarded, if data for common equity, total assets, number of outstanding shares, sales, cost of goods sold, gross profit, net income, return on assets, return on equity, return on investments, EPSO from operations, and EPSI were missing. Besides, only those firms which have at least five years of data, in the window between two years before and two years after the certification were retained. Out of the initial sample of 1223 companies that received the ISO certification between March 1, 1991 and February 24, 2003, 448 remained.

Figure 1 shows the break up the number of certification before and after the data cleaning. The number of certification per year increases from 2 in 1991 to 101 in 1998 and finally drops to 2 in year 2003. The reason for only two firms in 2003 is that our sample stops in February of 2003. The number of ISO firms after cleaning increased from 1 in 1991, reaches a maximum of 66 in 1998, and decreases to 39 for 2002. Table 1 shows the number of certified firms per industry, taking only the year of certification in consideration. Table 1 also shows the mean size and book to price values of the certified firms and those of the respective industry.

Using the data from CRSP and COMPUSTAT, size, and book to price (BP) are estimated using the formulae below.

Size $=\log _{\mathrm{n}}[($ price $) \mathrm{x}($ number of shares outstanding $)]$

$$
\mathrm{BP}=\log _{\mathrm{n}}\left(\frac{\text { Common Equity }}{\text { (price) } \mathrm{x}(\text { number of shares outstanding })}\right)
$$

The formula used to estimate size and book to price is the same as that used by Fama and French (1992). In order to get proper comparisons, sales, COGS, gross profit, and net income are scaled by total assets (Barker and Lyon, 1996). Scaling by total assets also allows us to observe how efficiently the assets are used by the firms in question.

The control firms are selected using three variables and the industry averages. In the year of the certification, stocks that are closest in size, book to price and return on assets to that of the certified firms form three different control groups. The control firms also have to be in the same industry as the certified firm. The total number of firms in each control group, except for the industry, is the same as that of the certified firms. We select size and ROA, because Barber and Lyon (1996) also use size and operating performance match for selecting control firms. We use book to price, because Fama and French (1992) show it to an important indicator for investor perception about earning prospect. We also look at the mean industry values to see how the certified firm performed with respect to the industry. The industry averages includes all the firms in the industry including the ISO certified firm. To avoid the impact of extreme values while comparing with industry, the values of the variables are windorized at the $1^{\text {st }}$ and $99^{\text {th }}$ percentiles. Basically, if the value of variable is below or above the $1^{\text {st }}$ or above the $99^{\text {th }}$ percentiles they are replaced by the $1^{\text {st }}$ and $99^{\text {th }}$ percentile values respectively. Table 2 presents mean values for the selected variables sales, cost of goods sold, gross profit, net income, EPSO, EPSI ROE, ROA, and ROI - through the event window ranging from two years prior to two years after the certification. The variables are averaged each year for the ISO certified firms, and the control firms.

\footnotetext{
${ }^{4}$ The financial earnings per share is COMPUSTAT data item number is A53. This includes all extraordinary items and discontinued operations. It takes into effect conversion of convertible preferred stock, convertible debt and options and warrants.

${ }^{5}$ The SIC code in the year of the certification is maintained as the industry classification for the event window of two years before and three years after certification. This was important, as the SIC classification for a few firms were observed to change during the event window.
} 
Tables 3 and 4, estimates and tests abnormal performance of ISO certified firms. Abnormal performance is the difference between the actual performance and the expected performance. The expected performance in Table 3, is the previous year's performance of the ISO certified firms, while in Table 4, the expected performance is the performance of the control firms.

$$
A P_{i, t}=P_{i, t}-E\left(P_{i, t}\right)
$$

Here AP is the abnormal performance of variable $\mathrm{i}$ in time $\mathrm{t}, \mathrm{P}_{\mathrm{i}, \mathrm{t}}$ is the actual performance in time $t$, while $\mathrm{E}\left(\mathrm{P}_{\mathrm{i}, \mathrm{t}}\right)$ is the expected performance. The abnormal performance is estimated for each of the variables, and then the null hypothesis of abnormal performance equal to zero is tested using a parametric t-test with student t-distribution. A positive value indicates that the actual performance is greater than the expected performance. Differences are tested at 1,5 and 10 percent levels.

We also investigate if the investor's perception of the change in the quality of the earnings by investigating the price earning (PE) ratios using both EPSO and EPSI for ISO certified firms and the control firms. The rationale is that investor's perception about the quality of earnings will determine the amount they are willing to pay for the earnings. The better the quality of earnings, the higher the amount they will be willing. While carrying out this investigation, we consider only those firms with positive EPSO and EPSI. Table 5 presents the results.

\section{RESULTS}

From Table 1, we can see that the largest number of firms are in the industry related to electronics (95, SIC code 36 ), followed by the industry related to machinery, machinery accessories, and computers accessories (65, SIC code 35). In terms of the percentage of firms of a particular industry obtaining certification, the highest is in industry with SIC code 52, were one out of the 7 firms have a certification, while the lowest is in the industry with SIC code 60 , where only two of the 876 firms have obtained certification.

Out of 42 industries that are considered in our sample, 15 industries have only one remaining firm, and 7 with only two after data cleaning. Of the 42 industries that remain in the sample, the mean size value of the certified firms in 38 industries is larger than the respective mean industry value. Three of the four industries, were the mean size values of the certified firms are less than the industry values, have only one firm, while one industry (SIC code 87) has 6. This observation supports that contention that the larger firms are more likely to attempt to obtain quality certification. This has also been alluded to by a number of other researchers including Bendell and Boulter (2004).

Table 1 also shows that in 28 of 42 industries have mean book to price value of certified firms are less than those of the respective industries. Of 14 industries, where the mean book to price values of certified firms is greater than that of the respective industries, most either have a small number of firms, or the percentage of certified firms is small. This probably means, that by and large, investors may feel, that ISO certified firms are less risky, and hence are willing to pay more to own shares.

Table 2 presents the means of sales, cost of goods sold (COGS), gross profit (GP), net income (NI), operating earnings per share (EPSO), basic earnings per share that includes extra-ordinary items (EPSI), return on equity (ROE), return on assets (ROA), and return on investments (ROI), for the ISO certified firms and the control firms. Sales, COGS, GP and NI are scaled by total assets. The figures reflect the sales, COGS, GP, and NI per unit of total assets employed. Thus these variables also reflect how effective the firms have been in using their assets. For the ISO certified firms, sales decrease from 1.22 to 1.15 dollars per unit of total assets, from two years before to two years after the certification. Over the same period, the sales figures dropped from 1.13 to 1.08 dollars for size control firms, from 1.34 to 1.32 dollars for book to price control firms, 1.20 to 1.18 dollars for return on assets control firms, and from 1.24 to 1.04 for the industries to which the certified firms belong. If we look at sales number of the ISO certified firms only, we may conclude that as far as effective utilization of assets for sales purposes, the quality certification does not help. If we look at sales numbers in the context that it decreases for all control groups as well as for the industry, one explanation for the drop in sales per unit of total assets could be due do the economic cycle that this article is investigating. Over eighty percent of the firms investigated in this sample obtained their 
certification during the 1990s, which is popularly accepted as a period of great economic prosperity. For most firms, ISO certified and control, the pre-certification sales would be higher than the post certification, and this perhaps may explain, why we observe the drop in sales.

The COGS for certified firms drops from 0.81 to 0.77 dollars per dollar of sales for the ISO certified firms, while it decreases from 0.76 to 0.72 for size control, and 0.85 to 0.72 for the industries of the ISO certified firms. For the book to price and the return on assets control firms, the COGS remains stable over the event window. The gross profit of ISO certified firms, and control firms based on size, book to price, and return on assets, as well as those of the industries drop over the event window in consideration. Net income also decreases over the event window, although the drop for the ISO certified firms is not as bad as those of the control firms. For example, net income drops from 0.04 to 0.02 for ISO certified firms, while the drop is from 0.04 to 0.00 for the size control firm, 0.02 to -0.01 for the book to price and return on asset control firms, and 0.01 to -0.03 for the industries.

The best support for the operating benefits from the ISO certification comes from the operating earnings per share, and the basic earnings per share that includes extra-ordinary items. Post certification EPSO and EPSI are larger than pre-certification for the ISO certified firms, but not so for the size, book to price control firms, and the industries as a whole. For the return on asset control firms, they increase till the certification year, and then subsequently drop. As far as the return on equity, the return on assets, and the return on investments are concerned, they drop for both the ISO certified firms, and the control firms. The drop for the ISO certified firms is not as sever as that of the control firms.

The basic conclusion from this Table is that evidence for support for the contention that quality certification leads to operating and financial performance benefits for a firm is by and large mixed. Except for EPSO and EPSI, all the other variables considered in this paper, may actually indicate that the ISO certification does not lead to improvement in operating, financial or investment performance. Besides, it is possible that the economic cycle may also play a role in determining the benefits of the ISO certification.

Table 3 and Table 4 present the results of abnormal performance of the ISO certified firms. The abnormal performance is the difference between the performance of the certified firms and the expected performance. In Table 3 , the expected performance is the previous year's performance, while in Table 4 , it is the performance of the control group.

From Table 3 we can see that the abnormal performance is always negative, indicating that the actual performance is less that the expected performance. Some the differences are at $1 \%$ significance level (highlighted values), while others are at 5\% and 10\% levels (indicated, respectively, with superscripts $a$ and $b$ ). At first look, once again, one may conclude that when compared to year to year performances, there is no benefit to quality certification, if the benefits are measured by sales, GP, NI, EPSO, EPSI, ROE, ROA, and ROI. While considering the results of this table, in the context of economic cycles, this table may only be reflecting the consequences of the downturn of the economy. A negative value for the COGS indicates that at least in terms of managing the cost of production or services offered, the ISO certified firms are able to obtain some benefit from certification. The benefit from cost management is maximum when actual performance is compared to the performance in the year before the certification.

In Table 4 we can observe that when compared to control firms the performance of ISO certified firms outperform for some variables in some of the years. For example, when compared to size control firms, sales, net income, EPSO and EPSI outperforms both before in and after certification. If performance is measured by gross profit, significant differences are observed only in the years before certification. Similarly, return on investments outperforms a year prior to certification, while significant difference in return on equity is observed only in the year after certification.

When performance of ISO certified firms are compared to book to price variables, significant difference in performance is observed for all variables except for gross profit. Book to price control firms on an average provide better sales, but the do not manage their costs as efficiently, so much so that the better sales is almost exactly 
matched by increases in COGS. Gross profit of ISO and book to price control firms are not significantly different form each other. Net income, EPSO, EPSI, ROA and ROI perform better for ISO certified firms than control firm for all the years in the event window. In some cases, the magnitude of the difference increases after certification. Return on investment is significantly different only in the year, and the year following certification.

For the control group using return on assets, significant differences in performance is not usually observed. Differences are observed in net income, return on assets ${ }^{6}$ and return on investment in the two years prior to certification and the second year after certification. Performance measured by EPSO and EPSI are significantly different only in the second year after certification. Whenever significant differences are observed, the ISO certified firms outperforms.

When compared to the mean performance of the respective industries, the ISO certified firms provide better performance, except for a few cases. Sales are better for the industry in the year of the certification, and cost of goods sold is better for the industry two years after certification.

The best support for argument that benefits exists for the quality certification if a variable shows adverse performance prior to certification and favorable performance after certification. Unfortunately, we do not observe that in our sample. If variables outperform for the ISO certified firms, they usually do so both before and after certification. For some variables, with respect to some control groups, the performance is better after than that before certification. Hence, although conclusive evidence for the benefits for certification is not observed in this article, benefits from certification may accrue to ISO certified firms.

Table 5 present the investors perception about the quality of earning performance of the ISO certified and the control firms. The contention here is that if investors perceive the earnings of quality certified firms to better than that of the control firms, they will be willing to pay more for each dollar of earnings. In Table 5, the price earning ratios are estimated using the operating earnings per share (operating price earning ratio), and basic earnings per share inclusive of extra-ordinary items (financial price earning ratio). Looking at the absolute values of the price earning ratio, the values decrease from the period before certification to the period after certification for the certified firms and their control firms. This observation may perhaps just be due to the economic cycle that we have mentioned before. Looking at the differences, investors do not usually perceive any difference in the quality of earnings between ISO certified firms and their size control firms. Only significant difference is found for the financial price earning ratio two years prior to certification, when the ISO firm has a better ratio, and the year after certification, when the size control firm has a better ratio. Both differences are significant only at ten percent levels.

ISO certified firms have better operating price earning ratios than their book to price counter parts, and better financial price earning ratios two years before and one year after certification. The strongest support for a better quality of earnings for ISO certified firms is observed when performance is compared to the industry. In the year prior to and after certification investors usually do not perceive a higher quality for operating earnings, although in the year of the certification, investors are willing to pay at least 14.00 more for operating earnings for the certified firms. In the year of the certification, investors are willing to pay more for the financial earnings as well, however the perception of higher quality of financial earnings per share disappears within one year of certification.

\section{CONCLUSION}

Although the ISO 9000 quality certificate has been around for almost a decade, controversy surrounds the benefits of certification. While Corbett, Montes-Sancho, and Kirsch (2005) finds the certification to benefit performance, Corbett, Montes Kirsch and Alvarez-Gil (2002) show that most of the benefits, when comparing to control groups, are actually realized before the certification. The findings of this paper are mixed as far as the

\footnotetext{
${ }^{6}$ The return on assets of the ISO certified firms in the certification year is not significantly different from that of the return on assets control firms. This basically confirms that the control firms selected on the basis of return on assets closely match the performance of the ISO certified firms.
} 
operating and financial performance benefits are concerned. When comparing to control firms, ISO certified firms may perform better with respect to some control firms like the book to price and the industry as a whole. When size and return on assets is used to identify the control firms, support for better performance by ISO certified firms is weak. Better performance by ISO certified firms also depends on the variable that is considered.

One should also note that with respect to the variables and the control groups where the ISO certified firms show better performance, a dramatic shift in performance is not usually observed pre and post event. The difference in the findings of this article and that of Corbett, Montes-Sancho, and Kirsch (2005) may be explained by sample period differences, and the timing of selection of the control group. For a large number of firms in our sample, the post event falls in the slowing down in the economy in the late 1990s and the earlier part of this decade. Besides, we select the control firms in the year of the certification, while Corbett, Montes-Sancho, and Kirsch (2005) select their control firms two years prior to certification. While comparing year to year performance, we also do not always find a superior performance of certified firms post certification. While investigating the investors' perception about the quality of earnings of certified firms to those of the control firms, we do not find a dramatic difference in perception.

Considering the findings of both this paper and that of Corbett, Montes-Sancho, and Kirsch (2005), we may conclude that the benefits of certification may depend on the types of firms considered in the sample, the control group used for comparison, and the economic cycle of the sample period considered. It is also possible that firms may opt for the certification for non-performance related issues. Anderson, Daly and Johnson (1999) discuss some of the factors that may influence the decision to pursue the ISO 9000 quality certification.

\section{AUTHOR INFORMATION}

Dale Varble is Associate Dean, Director of the MBA program and Professor of Marketing in the College of Business at Indiana State University. He is the co-author of two textbooks in marketing and one case book. He has also published in the Review of Quantitative Finance and Accounting, Journal of Marketing and Journal of Retailing. In addition he has had papers presented at the Academy of Financial Services, Marketing Management Association and American Marketing Association Annual Conferences. His current research interest focuses on marketing strategy, specifically quality as a competitive advantage.

\section{REFERENCES}

1. Anderson, S. W., Daly, J. D., and Johnson, M. F.; (1999); Why firms set ISO 9000 certification: Regulatory compliance or competitive advantage; Production and Operations Management; v8; pp28-43

2. Barber, B. M, and Lyon, J. D.; (1997); Detecting long-run abnormal stock returns: The empirical power and specification of test statistics; Journal of Financial Economics; v43; pp341-372

3. Beirao, G., Cabral, J. A. S.; (2002); The reaction of the Portuguese stock market to ISO 9000 certification; Total Quality Management, v 13n 4, pp 465- 474

4. Chittenden, F., Poutziouris, P, and Mukktar, S.M.; (1998); Small firms and the ISO 9000 approach to quality management; International Small Business Journal; v38n1; pp 52-57

5. Corbett, C. J., Montes-Sancho, M. J., Kirsch, D. A.; (2005); The Financial Impact of IOS 9000 Certification in the United States: An Empirical Analysis; Management Science; v51n7; pp 1046-1059

6. Corbett, C. J., Montes, M. J., Kirsch, D. A., and Alvarez-Gil, M. J.; (2002); Does ISO certification pay?; ISO Management Systems; July-August; pp 31-40

7. $\quad$ Dalgleish, S.; (2002); ISO 9000: More hindrance than help; Quality; v41n10; pp 64-64

8. Fama, Eugene F., and Kenneth R. French (1993); Common risk factors in the returns on stocks and bonds, Journal of Financial Economics; v49; pp 3-56

9. Ferreira, E., Sinha, A. K., Varble, D., (2006); Long-run Performance following Quality Management Certification; Under-review at Review of Quantitative Finance and Accounting

10. MacAdam, R., and McKeown., M.; (1999); Life after ISO: an analysis of the impact of ISO 9000 and total quality management on small business in Northern Ireland; Total Quality Management; v10; 229-241

11. Puderbach, L, and Brown, K, (1998); Financial effects of ISO 9000 certification in American corporations; Proceedings of the Decision Sciences Institute, Las Vegas. 
12. Quaze, H. A., Hong, C. W., and Meng, C. T.; 2002; Impact of ISO 9000 certification on quality management practices: A comparative study; Total Quality Management v13n1, pp53-67

13. Sharma, D. S.; (2005); The association between ISO 9000 certification and financial performance; The International Journal of Accounting; v40n; pp151- 172

14. Simmons, B. L., \& White, M. A; (1999); The relationship between ISO 9000 and Business performance: Does registration really matter?; Journal of Managerial Issues; v11n3; pp 330-343

15. Sun, H; (1999); Diffusion and contribution of the total quality management: an empirical study in Norway; Total Quality Management; v10; 901-914

16. Terziovski, M, Samson, D and Dow, D; (1997); The business value of quality management systems certification: evidence from Australia and New Zealand; Journal of Operations Management, v15, pp 1-18

17. Wayhan, V. B., Kirche, E. T., and Khumawala, B. M.; (2002); ISO 9000 certification: The financial performance implications; Total Quality Management; v13n2; 217-231

\section{NOTES}


Figure 1: Number of Firms Obtaining ISO Certification

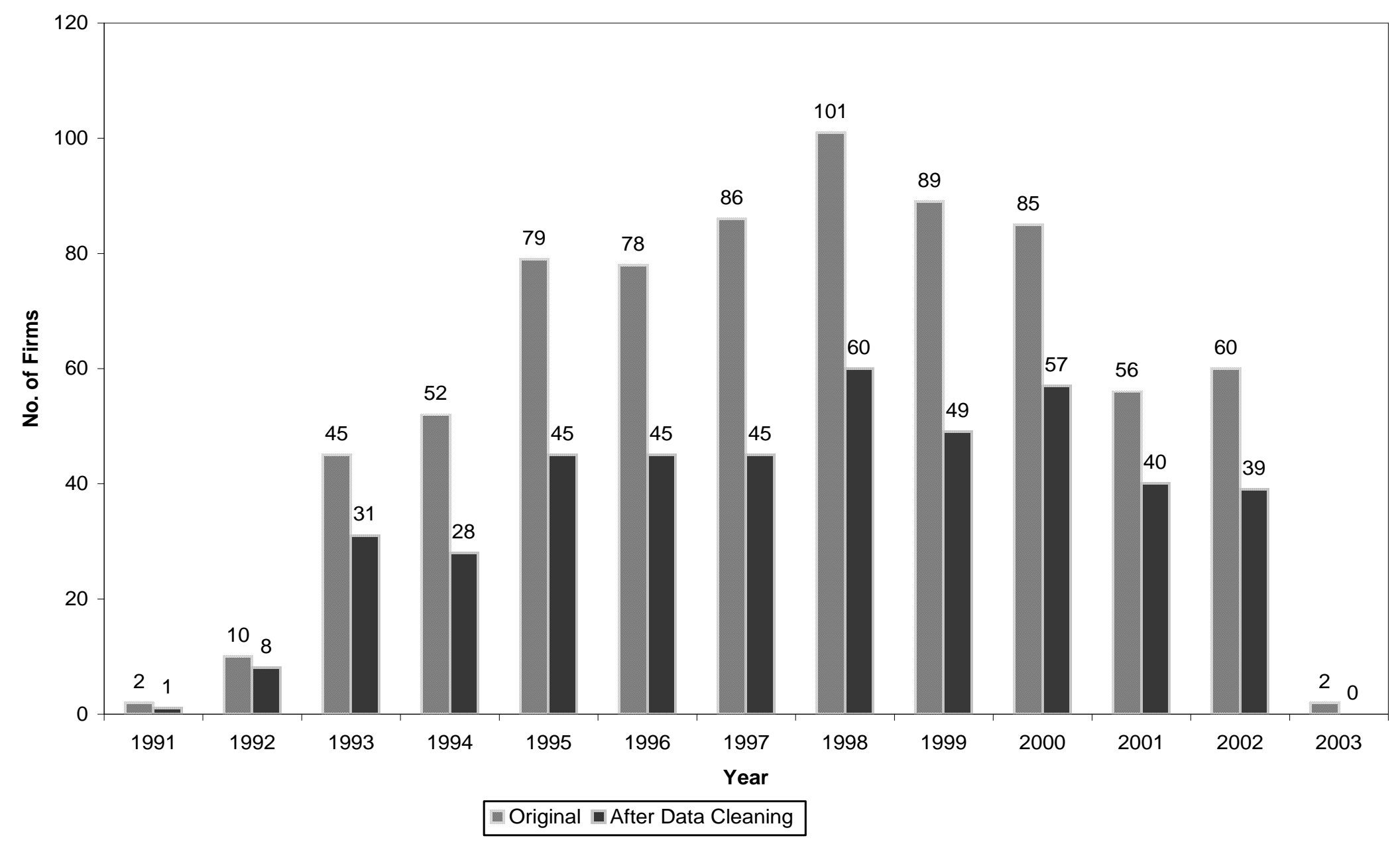


Table 1: Number and Industry of Number of Certified Firms

\begin{tabular}{|c|c|c|c|c|c|c|c|}
\hline \multirow{2}{*}{ SIC } & \multirow{2}{*}{ Industry } & \multicolumn{3}{|c|}{ ISO Firms } & \multicolumn{3}{|c|}{ ISO Industry } \\
\hline & & $\mathbf{N}$ & Size & BP & $\mathbf{N}$ & Size & BP \\
\hline 13 & Oil and Gas Extraction & 4 & 13.53 & -7.64 & 454 & 12.19 & -7.62 \\
\hline 14 & Mining \& Quarrying of Nonmetallic & 1 & 13.22 & -8.55 & 11 & 12.13 & -7.42 \\
\hline 16 & Heavy Construction- Not Building Const. & 3 & 13.00 & -7.65 & 37 & 12.44 & -7.36 \\
\hline 20 & Food and Kindred Products & 2 & 16.26 & -7.88 & 172 & 12.90 & -7.98 \\
\hline 22 & Textile Mills Products & 3 & 13.59 & -8.09 & 54 & 12.07 & -7.42 \\
\hline 23 & Petroleum Refining and Related Products & 1 & 12.21 & -6.61 & 41 & 11.85 & -7.17 \\
\hline 24 & Lumber and Wood Products & 2 & 16.23 & -8.08 & 37 & 12.72 & -7.58 \\
\hline 25 & Furniture and Fixtures & 4 & 13.41 & -7.37 & 74 & 12.84 & -7.84 \\
\hline 26 & Paper and Allied Products & 18 & 14.11 & -7.90 & 285 & 13.38 & -7.48 \\
\hline 27 & Printing, Publishing and Allied & 1 & 15.01 & -7.35 & 52 & 13.03 & -7.77 \\
\hline 28 & Chemicals and Allied Prodicts & 40 & 14.39 & -8.41 & 3376 & 12.42 & -8.23 \\
\hline 29 & Petroleum Refining and Related Products & 4 & 15.85 & -8.08 & 102 & 15.27 & -7.87 \\
\hline 30 & Rubber and Miscellaneous Products & 14 & 11.92 & -7.48 & 411 & 11.71 & -7.49 \\
\hline 32 & Stone, Clay, Glass, Concrete Products & 4 & 13.02 & -7.18 & 67 & 12.64 & -7.34 \\
\hline 33 & Primary and Metal Industries & 18 & 13.09 & -7.55 & 578 & 12.61 & -7.38 \\
\hline 34 & Fabricated Metals, Ex Machine Trans Eq & 10 & 12.48 & -7.54 & 321 & 12.04 & -7.40 \\
\hline 35 & Indl, Comml Machy, Computer Eq & 65 & 13.50 & -8.10 & 2706 & 12.28 & -7.88 \\
\hline 36 & Electr. Oth Elec Eq, Ex Cmp & 95 & 13.08 & -8.28 & 3223 & 12.31 & -7.92 \\
\hline 37 & Transportation Equipment & 27 & 14.06 & -7.89 & 690 & 13.01 & -7.66 \\
\hline 38 & Meas Instr: Photo GDs; Watches & 57 & 12.82 & -8.11 & 2633 & 11.70 & -8.04 \\
\hline 39 & Misc Manufacturing Industries & 2 & 12.18 & -7.04 & 77 & 11.54 & -7.65 \\
\hline 40 & Railroad Transportation & 3 & 16.45 & -8.07 & 35 & 13.85 & -7.38 \\
\hline 42 & Motor Freight Trans, Warehouse & 4 & 13.08 & -8.56 & 119 & 12.09 & -7.28 \\
\hline 44 & Water Transportation & 1 & 15.01 & -8.10 & 15 & 13.29 & -7.61 \\
\hline 45 & Air - Transportation, Courier, Airports & 1 & 13.01 & -8.11 & 31 & 13.04 & -7.33 \\
\hline 47 & Transportation Services & 2 & 13.19 & -8.05 & 21 & 12.69 & -7.82 \\
\hline 48 & Communications & 2 & 15.40 & -8.05 & 253 & 13.60 & -7.73 \\
\hline 49 & Electric, Gas, Sanitary Services & 1 & 15.77 & -7.33 & 149 & 13.92 & -7.54 \\
\hline 50 & Durable Goods Warehouse & 21 & 12.46 & -7.31 & 790 & 11.64 & -7.36 \\
\hline 51 & Nondurable Goods Warehouse & 1 & 11.06 & -6.62 & 58 & 11.94 & -7.61 \\
\hline 52 & Retail - Building, Hardware, Lumber, etc. & 1 & 14.95 & -10.73 & 7 & 13.58 & -8.82 \\
\hline 53 & Retail - Department, and Gen Merchandise & 1 & 15.84 & -7.02 & 29 & 13.89 & -7.18 \\
\hline 55 & Retail - Apparel, Shoes & 1 & 10.74 & -6.67 & 21 & 11.35 & -6.39 \\
\hline 56 & Retail-Eating Places & 1 & 16.44 & -8.23 & 50 & 12.94 & -7.50 \\
\hline 58 & Retail-Miscellaneous Retail & 1 & 13.24 & -7.19 & 61 & 11.48 & -7.61 \\
\hline 59 & Holding, Other Investment Offices & 1 & 15.34 & -8.68 & 73 & 12.17 & -7.56 \\
\hline 60 & Services-Personal Services & 2 & 14.67 & -8.09 & 876 & 12.44 & -7.77 \\
\hline 67 & Services-Amusement, Recreation, Sports etc & 1 & 13.15 & -9.05 & 202 & 12.52 & -7.48 \\
\hline 73 & Health Services & 20 & 13.37 & -8.12 & 4131 & 12.03 & -8.01 \\
\hline 79 & Educations Services & 1 & 12.27 & -6.47 & 42 & 12.22 & -7.21 \\
\hline 87 & Engr, Acc, Resh, Mgmt, Rel Svs & 6 & 11.15 & -7.20 & 339 & 11.67 & -7.79 \\
\hline 99 & Services, Nec & 1 & 20.59 & -10.53 & 16 & 12.04 & -7.69 \\
\hline
\end{tabular}

This table provides the mean size, mean book to price values, and the industries of the ISO-9000 certified firms in the sample after data cleaning. The total number of firms in the sample is 448 , and the number of industries is 42 . The table also provides the number of firms in the corresponding industry in the year of the certification, and the mean size and book to values. 
Table 2: Mean Performance of ISO Certified and Control Firms

\begin{tabular}{|c|c|c|c|c|c|c|c|c|c|}
\hline \multirow{2}{*}{$\begin{array}{l}\text { Ref. } \\
\text { Year }\end{array}$} & \multicolumn{9}{|c|}{ Variables } \\
\hline & Sales & COGS & GP & NI & EPSO & EPSI & ROE & ROA & ROI \\
\hline \multicolumn{10}{|c|}{ Panel A: ISO Firms } \\
\hline-2 & 1.22 & 0.81 & 0.41 & 0.04 & 0.83 & 0.67 & 18.81 & 4.53 & 6.82 \\
\hline-1 & 1.20 & 0.80 & 0.40 & 0.04 & 0.92 & 0.74 & 5.68 & 4.00 & 6.12 \\
\hline 0 & 1.16 & 0.77 & 0.39 & 0.04 & 0.89 & 0.75 & 7.93 & 3.67 & 5.77 \\
\hline 1 & 1.14 & 0.77 & 0.38 & 0.02 & 0.90 & 0.80 & 4.07 & 2.01 & 2.25 \\
\hline 2 & 1.15 & 0.77 & 0.38 & 0.02 & 0.96 & 0.75 & 0.77 & 1.98 & 2.65 \\
\hline \multicolumn{10}{|c|}{ Panel B: Size Control Firms } \\
\hline-2 & 1.13 & 0.76 & 0.37 & 0.04 & 0.72 & 0.63 & 5.11 & 3.88 & 6.46 \\
\hline-1 & 1.12 & 0.76 & 0.36 & 0.02 & 0.80 & 0.57 & 2.50 & 2.51 & 1.84 \\
\hline 0 & 1.13 & 0.76 & 0.37 & 0.02 & 0.71 & 0.42 & 8.56 & 2.56 & 3.97 \\
\hline 1 & 1.12 & 0.76 & 0.36 & -0.01 & 0.56 & 0.27 & -32.71 & -0.36 & -0.31 \\
\hline 2 & 1.08 & 0.72 & 0.36 & 0.00 & 0.68 & 0.42 & -0.99 & 0.83 & 1.42 \\
\hline \multicolumn{10}{|c|}{ Panel C: Book to Price Control Firms } \\
\hline-2 & 1.34 & 0.93 & 0.41 & 0.02 & 0.51 & 0.37 & 2.60 & 1.30 & 1.71 \\
\hline-1 & 1.35 & 0.94 & 0.41 & 0.00 & 0.46 & 0.20 & 1.82 & 0.46 & -0.01 \\
\hline 0 & 1.32 & 0.92 & 0.40 & 0.00 & 0.42 & 0.09 & 0.03 & -0.13 & -1.06 \\
\hline 1 & 1.30 & 0.93 & 0.37 & -0.04 & 0.39 & 0.18 & -9.70 & -4.84 & -10.26 \\
\hline 2 & 1.32 & 0.93 & 0.40 & -0.01 & 0.50 & 0.27 & -3.04 & -1.15 & -3.88 \\
\hline \multicolumn{10}{|c|}{ Panel D: ROA Control Firms } \\
\hline-2 & 1.20 & 0.81 & 0.39 & 0.02 & 0.67 & 0.53 & 4.47 & 2.03 & 3.51 \\
\hline-1 & 1.20 & 0.81 & 0.39 & 0.02 & 0.74 & 0.61 & -0.87 & 2.07 & 2.77 \\
\hline 0 & 1.19 & 0.80 & 0.39 & 0.03 & 0.88 & 0.68 & 6.72 & 3.62 & 5.72 \\
\hline 1 & 1.18 & 0.80 & 0.38 & 0.02 & 0.84 & 0.62 & 4.12 & 2.00 & 2.76 \\
\hline 2 & 1.18 & 0.81 & 0.37 & -0.01 & 0.74 & 0.35 & -8.60 & -0.71 & -2.01 \\
\hline \multicolumn{10}{|c|}{ Panel E: SIC Controls Firms } \\
\hline-2 & 1.24 & 0.85 & 0.40 & 0.01 & 0.40 & 0.14 & -3.62 & 0.47 & 0.19 \\
\hline-1 & 1.22 & 0.83 & 0.39 & -0.01 & 0.39 & 0.06 & -6.11 & -0.36 & -0.96 \\
\hline 0 & 1.29 & 0.96 & 0.33 & 0.00 & 0.33 & 0.22 & 1.42 & 0.13 & 1.34 \\
\hline 1 & 1.07 & 0.74 & 0.33 & -0.04 & 0.33 & 0.09 & -14.68 & -4.51 & -7.06 \\
\hline 2 & 1.04 & 0.72 & 0.32 & -0.03 & 0.32 & 0.42 & -12.71 & -3.17 & -4.95 \\
\hline
\end{tabular}

This table provides the mean values for the ISO certified firms, and control firms selected on the basis of size, book to price, and return on asset, besides the industry averages over the event window, ranging from two years before to two years after the certification. COGS $=$ Cost of Goods Sold. GP $=$ Gross Profit, as reported in COMPUSTAT. NI $=$ Net Income. EPSI $=$ All Inclusive Earnings per Share, as reported in COMPUSTAT. EPSO = Operating Earnings per Share as reported in COMPUSTAT. Sales, COGS, GP and NI in this table are scaled by Total Assets. ROE = Return on Equity. ROA = Return on Assets. ROI = Return on Investments. ROA, ROE and ROI are in percentage. Ref. Year is the Reference year, and values $-2,-1$ means two years, and one year prior to certification,; 0 is the year of the certification, while 1 and 2 are one and two years after certification. 
Table 3: Lagged Abnormal Performance of ISO Certified Firms

\begin{tabular}{c|cccc}
\hline Variables & $\mathbf{Y}(\mathbf{- 1})-\mathbf{Y}(\mathbf{- 2})$ & $\mathbf{Y}(\mathbf{0})-\mathbf{Y}(\mathbf{- 1})$ & $\mathbf{Y}(\mathbf{1})-\mathbf{Y}(\mathbf{0})$ & $\mathbf{Y}(\mathbf{2})-\mathbf{Y}(\mathbf{1})$ \\
\hline Sales & -0.01 & $\mathbf{- 0 . 0 4}$ & $-0.02^{\mathrm{b}}$ & 0.01 \\
COGS & -0.01 & $\mathbf{- 0 . 0 3}$ & -0.01 & 0.00 \\
GP & -0.01 & $\mathbf{- 0 . 0 1}$ & $\mathbf{- 0 . 0 1}$ & 0.00 \\
NI & -0.01 & 0.00 & $\mathbf{- 0 . 0 2}$ & 0.00 \\
EPSO & $0.09^{\mathrm{a}}$ & -0.03 & 0.02 & 0.06 \\
EPSI & 0.07 & 0.00 & 0.05 & -0.05 \\
ROE & -13.14 & 2.26 & $-3.86^{\mathrm{b}}$ & -3.30 \\
ROA & -0.54 & -0.32 & $-1.66^{\mathrm{a}}$ & -0.03 \\
ROI & -0.70 & -0.35 & $-3.52^{\mathrm{a}}$ & 0.40 \\
\hline
\end{tabular}

This table provides the results for the year to year changes for ISO firms. The numbers are difference in the performance of a year and the previous year. A negative value indicates that the prior year has performed better. $\mathrm{Y}(-1)-\mathrm{Y}(-2)$ represents the difference between the year before certification, and two years before certification. $Y(0)-Y(-1)$ represents the difference between the year of certification, and the year before certification. $Y(1)-Y(0)$ represents the difference between the year after certification, and the year of certification. $\mathrm{Y}(2)-\mathrm{Y}(1)$ represents the difference between the year two years after certification, and the year after certification. COGS $=$ Cost of Goods Sold. GP $=$ Gross Profit, as reported in COMPUSTAT. NI $=$ Net Income. EPSI = All Inclusion Earnings per Share, as reported in COMPUSTAT. EPSO = Operating Earnings per Share as reported in COMPUSTAT. Sales, COGS, GP and NI in this table are scaled by Total Assets. ROE = Return on Equity. ROA = Return on Assets. ROI = Return on Investments. Highlighted values indicate difference at $1 \%$ level, while superscripts a and $\mathrm{b}$ indicate difference at 5 and 10 percent levels. 
Table 4: Performance of ISO Certified Firms compared to Control Firms

\begin{tabular}{|c|c|c|c|c|c|c|c|c|c|}
\hline \multirow{2}{*}{$\begin{array}{l}\text { Ref. } \\
\text { Year }\end{array}$} & \multicolumn{9}{|c|}{ Variables } \\
\hline & Sales & COGS & GP & NI & EPSO & EPSI & ROE & ROA & ROI \\
\hline & \multicolumn{9}{|c|}{ Panel A: Size Control Firms } \\
\hline-2 & $0.09^{\mathrm{a}}$ & 0.05 & 0.04 & 0.01 & 0.11 & 0.05 & 13.81 & 0.70 & 0.45 \\
\hline-1 & $0.08^{\mathrm{a}}$ & 0.04 & 0.04 & $0.01^{\mathrm{b}}$ & $0.12^{\mathrm{b}}$ & $0.17^{\mathrm{a}}$ & 3.25 & $1.51^{\mathrm{b}}$ & $4.31^{\mathrm{b}}$ \\
\hline 0 & 0.03 & 0.01 & 0.02 & $0.02^{\mathrm{b}}$ & $0.18^{\mathrm{a}}$ & 0.32 & -0.56 & 1.12 & 1.82 \\
\hline 1 & 0.03 & 0.01 & 0.02 & $0.02^{\mathrm{a}}$ & 0.34 & 0.52 & 36.82 & $2.36^{\mathrm{a}}$ & 2.55 \\
\hline \multirow[t]{2}{*}{2} & $0.07^{\mathrm{a}}$ & 0.05 & 0.02 & $0.02^{\mathrm{b}}$ & 0.27 & 0.32 & 1.76 & 1.14 & 1.22 \\
\hline & \multicolumn{9}{|c|}{ Panel B: Book to Price Control Firms } \\
\hline-2 & -0.13 & -0.13 & 0.00 & $\mathbf{0 . 0 3}$ & 0.33 & 0.30 & 16.33 & 3.27 & 5.19 \\
\hline-1 & -0.15 & -0.14 & -0.01 & 0.03 & 0.46 & 0.54 & 3.93 & 3.56 & 6.16 \\
\hline 0 & -0.16 & -0.15 & -0.01 & 0.04 & 0.47 & 0.64 & 7.97 & 3.81 & 6.84 \\
\hline 1 & -0.16 & -0.16 & 0.00 & 0.06 & 0.51 & 0.62 & 13.80 & 6.84 & 12.51 \\
\hline \multirow[t]{2}{*}{2} & -0.18 & -0.16 & -0.02 & $\mathbf{0 . 0 3}$ & 0.45 & 0.47 & 3.80 & 3.12 & 6.53 \\
\hline & \multicolumn{9}{|c|}{ Panel C: Return on Asset Control Firms } \\
\hline-2 & 0.02 & 0.00 & 0.02 & 0.02 & 0.17 & 0.15 & 14.46 & 2.54 & 3.39 \\
\hline-1 & 0.00 & -0.01 & 0.01 & $\mathbf{0 . 0 2}$ & 0.18 & 0.14 & 6.62 & 1.95 & 3.38 \\
\hline 0 & -0.03 & -0.03 & 0.00 & 0.00 & 0.02 & 0.07 & 1.60 & 0.07 & 0.11 \\
\hline 1 & -0.04 & -0.03 & 0.00 & 0.00 & 0.06 & 0.18 & -0.02 & 0.00 & -0.51 \\
\hline \multirow[t]{2}{*}{2} & -0.03 & -0.04 & 0.01 & 0.03 & $0.21^{\mathrm{b}}$ & $\mathbf{0 . 3 9}$ & 9.36 & 2.68 & 4.66 \\
\hline & \multicolumn{9}{|c|}{ Panel D: SIC Control Firms } \\
\hline-2 & -0.03 & -0.04 & 0.01 & 0.04 & 1.05 & 0.53 & $22.43^{\mathrm{b}}$ & 4.07 & 7.36 \\
\hline-1 & -0.02 & -0.03 & 0.01 & 0.04 & 1.05 & 0.68 & $11.79^{\mathrm{a}}$ & 4.35 & 7.65 \\
\hline 0 & -0.13 & -0.19 & 0.06 & 0.04 & 0.38 & 0.52 & 6.51 & 3.54 & 5.83 \\
\hline 1 & 0.07 & 0.02 & 0.05 & 0.06 & 0.58 & 0.71 & 18.75 & 6.52 & 10.30 \\
\hline 2 & 0.11 & $0.05^{\mathrm{a}}$ & 0.06 & 0.05 & 0.37 & $\mathbf{0 . 3 3}$ & 13.48 & 5.15 & 8.68 \\
\hline
\end{tabular}

This table provides the results of the performance difference between ISO firms and the control firms, selected on the basis of size, book to price, return on assets, and corresponding industry. The size, book to price, and return on asset control firms and the closest in terms of values of these variables to the corresponding values of ISO firms. A positive value indicates that the ISO firms have performed better than the control firms. COGS = Cost of Goods Sold. GP = Gross Profit, as reported in COMPUSTAT. NI = Net Income. EPSI = All Inclusion Earnings per Share, as reported in COMPUSTAT. EPSO = Operating Earnings per Share as reported in COMPUSTAT. Sales, COGS, GP and NI in this table are scaled by Total Assets. ROE = Return on Equity. ROA = Return on Assets. ROI = Return on Investments. ROE, ROA and ROI are in percentage. Highlighted values indicate difference at $1 \%$ level, while superscripts a and $\mathrm{b}$ indicate difference at 5 and 10 percent levels. Ref year is the Reference year, and values $-2,-1$ means two years, and one year prior to certification; 0 is the year of the certification, while 1 and 2 are one and two years after certification. 
Table 5: Quality of Earnings Performance

\begin{tabular}{|c|c|c|c|c|c|}
\hline \multirow{3}{*}{ Price Earning Ratios } & \multicolumn{5}{|c|}{ Reference Year } \\
\hline & -2 & -1 & $\mathbf{0}$ & 1 & 2 \\
\hline & \multicolumn{5}{|c|}{ Panel A: ISO Firms } \\
\hline Operating & 71.94 & 57.00 & 41.96 & 40.03 & 38.75 \\
\hline \multirow[t]{2}{*}{ Financial } & 160.24 & 211.33 & 90.70 & 49.96 & 48.41 \\
\hline & \multicolumn{5}{|c|}{ Panel B1: Size Control Firms } \\
\hline Operating & 69.33 & 54.32 & 54.37 & 59.52 & 36.04 \\
\hline \multirow{2}{*}{ Financial } & 71.33 & 83.44 & 65.27 & 95.17 & 55.32 \\
\hline & \multicolumn{5}{|c|}{ Panel B2: Size Abnormal Performance } \\
\hline Operating & 12.70 & 10.48 & -7.98 & -16.57 & 6.41 \\
\hline \multirow{2}{*}{ Financial } & $117.87^{\mathrm{b}}$ & 171.66 & 41.97 & $-43.82^{b}$ & -2.98 \\
\hline & \multicolumn{5}{|c|}{ Panel C1: Book to Price Control Firms } \\
\hline Operating & 27.09 & 30.39 & 33.04 & 26.96 & 23.63 \\
\hline \multirow{2}{*}{ Financial } & 29.91 & 44.57 & 49.49 & 36.36 & 39.57 \\
\hline & \multicolumn{5}{|c|}{ Panel C2: Book to Price Abnormal Performance } \\
\hline Operating & 49.26 & 33.48 & $11.48^{\mathrm{b}}$ & 15.61 & 20.41 \\
\hline \multirow[t]{2}{*}{ Financial } & $161.04^{\mathrm{a}}$ & 238.29 & 46.51 & $14.32^{\mathrm{a}}$ & 14.46 \\
\hline & \multicolumn{5}{|c|}{ Panel D1: Return on Assets Control Firms } \\
\hline Operating & 67.49 & 63.29 & 42.49 & 39.34 & 46.33 \\
\hline \multirow[t]{2}{*}{ Financial } & 77.77 & 87.82 & 53.02 & 48.89 & 53.62 \\
\hline & \multicolumn{5}{|c|}{ Panel D2: Return on Assets Abnormal Performance } \\
\hline Operating & 7.91 & -8.49 & 0.22 & 2.28 & -7.75 \\
\hline \multirow[t]{2}{*}{ Financial } & 44.50 & 132.03 & $41.30^{\mathrm{a}}$ & 4.01 & -2.47 \\
\hline & \multicolumn{5}{|c|}{ Panel E1: SIC Control Firms } \\
\hline & 86.21 & 76.22 & 27.96 & 44.93 & 40.28 \\
\hline \multirow[t]{2}{*}{ Financial } & 91.22 & 98.08 & 48.89 & 58.95 & 49.11 \\
\hline & \multicolumn{5}{|c|}{ Panel E2: SIC Abnormal Performance } \\
\hline Operating & -14.26 & -19.22 & 14.00 & $-4.90^{\mathrm{b}}$ & -1.53 \\
\hline Financial & 69.02 & 113.25 & $41.81^{\mathrm{b}}$ & $-8.99^{b}$ & -0.70 \\
\hline
\end{tabular}

This table provides the results of the investors perception about the quality of earnings. Investors perceptions about the quality of earnings determine the amount they pay for the earnings. The operating price earning ratio is estimated using the operating earnings per share, while the financial price earning ratio is estimated using the basic earnings per share that includes extra item. While preparing this table, firms with negative earnings per share (both operating and financial) were discarded. A positive value for abnormal performance indicates that the ISO certified firms outperform the control firms. The highlighted values are significant at $1 \%$, while the superscripts a and $\mathrm{b}$ indicates significance at 5 and $10 \%$ levels. 